\title{
Combining Microfluidic Networks and Peptide Arrays for Multi-Enzyme Assays
}

\author{
Jing Su, Michelle R. Bringer, Rustem F. Ismagilov, ${ }^{*}$ and Milan Mrksich* \\ Department of Chemistry and the Institute for Biophysical Dynamics, The University of Chicago, \\ Chicago, Illinois 60637
}

Received March 3, 2005; E-mail: r-ismagilov@uchicago.edu; mmrksich@uchicago.edu

The development of assays that measure enzyme activities underlies much work in cell biology, clinical diagnostics, and drug discovery. Recent technical advances in microfluidic networks ( $\mu \mathrm{FNs})$ and in biochip microarrays have separately contributed to the development of assays that require few manipulations and that can simultaneously measure large numbers of activities. Microfluidic networks require small sample volumes and can integrate several sample processing steps on a single platform, ${ }^{1}$ while biochips allow multiple assays to be performed on a single sample. ${ }^{2}$ This paper reports a strategy for combining $\mu \mathrm{FNs}$ and biochip arrays to assay multiple enzyme activities in a sample.

Microfluidic networks have most commonly been used to perform homogeneous phase assays, ${ }^{3}$ but several recent examples have addressed solid-phase format assays. ${ }^{4}$ These examples have emphasized immunoassays to detect, or quantitate, analytes. The use of $\mu \mathrm{FN}$ to assay multiple enzymatic activities is much less common, in part, because the labeling protocols required to identify these activities add several additional steps to the assays.

We demonstrate the multi-analyte assay with a set of peptides that are selective substrates for a panel of kinase and phosphatase enzymes (Table 1)..$^{5}$ The peptides contain a terminal cysteine residue, which permits immobilization to a self-assembled monolayer presenting maleimide groups. ${ }^{6}$ To prepare the peptide arrays, we used a well-established "criss-cross" procedure for patterning. ${ }^{7}$ A poly(dimethylsiloxane) (PDMS) stamp having six parallel channels in negative relief (500 $\mu \mathrm{m}$ width, $50 \mu \mathrm{m}$ height) was applied to the monolayer, ${ }^{8}$ and separate aqueous solutions each containing a different peptide $(0.2 \mathrm{mM})$ were flowed into the channels in contact with the monolayer for $30 \mathrm{~min}$ (Figure 1A). The channels were emptied, and the stamp was removed, washed, and reapplied to the monolayer in a perpendicular orientation so that each channel intersected each of the six immobilized peptides. Solutions containing each of the six kinases were next flowed over the monolayers for $1 \mathrm{~h}$ at $150 \mathrm{~nL} / \mathrm{min} .{ }^{9}$ We then removed the stamp and used MALDI-TOF MS to analyze the 36 regions of the monolayer corresponding to treatment of each peptide with each of the kinases. ${ }^{10,11}$ Spectra corresponding to regions where peptides had been immobilized but not exposed to kinases showed expected peaks for cysteine-mediated immobilization of the peptide substrate (Figure 1B, ii). Only regions containing peptides that were exposed to specific kinases showed peaks corresponding to phosphorylation (iii).

Figure 2A summarizes the specificity of each kinase for the panel of peptides. ${ }^{12}$ The kinases showed the expected specificities toward the peptides. For example, the related kinases Abl and Src (and PKA and PKC) show a slight cross-reactivity for their peptide substrates. ${ }^{5}$

We next illustrate that the peptide arrays can be used to identify enzyme activities in a mixture of kinases. Using the technique described above, we assayed kinase and inhibitor activities simul-
Table 1. Peptide Substrates Used in Enzyme Assays

\begin{tabular}{lll}
\hline & \multicolumn{1}{c}{ peptides substrates } & \multicolumn{1}{c}{ enzymes } \\
\hline P1 & Ac-AIYAAPFKKGC-NH & \\
P2 & Ac-EEIYGEFEAKKKC-NH & Abl kinase \\
P3 & Ac-CKRRALS(p)VASLPGL-NH & Src kinase \\
& & $\begin{array}{l}\text { CK I kinase } \\
\text { phosphatase 2A,2C }\end{array}$ \\
P4 & Ac-TGPLSPGPFGC-NH & Erk-1 kinase \\
P5 & Ac-LRRASLGC-NH & protein kinase A \\
P6 & Ac-AKIQASFRGHMARKKGC-NH & protein kinase C \\
P7 & Ac-RKRSRAEC-NH & protein kinase G \\
PP1 & Ac-AIY(p)AAPFKKGC-NH & tyrosine phosphatase \\
PP5 & Ac-LRRAS(p)LGC-NH $\mathrm{NH}_{2}$ & alkaline phosphatase \\
& & \\
\hline
\end{tabular}

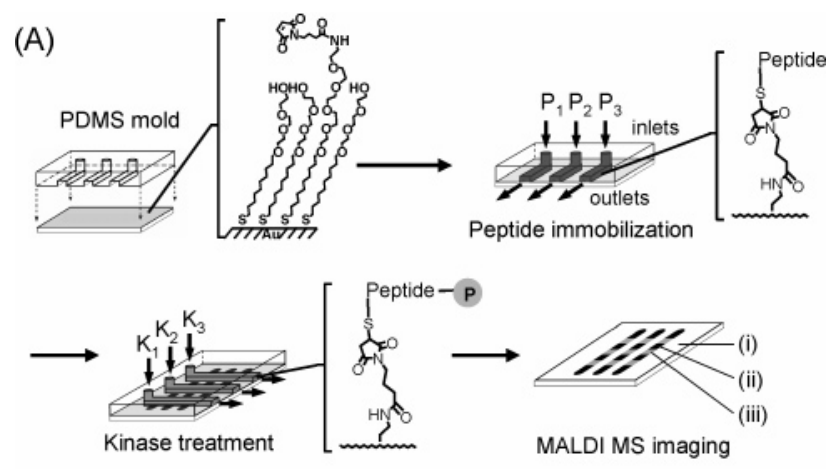

(B)

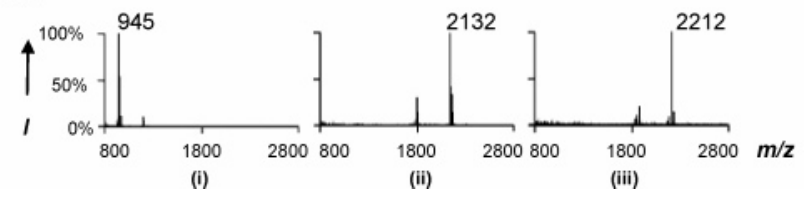

Figure 1. (A) This work describes the use of a $\mu \mathrm{FN}$ to prepare a peptide array and treat the array with samples that contain kinase and phosphatase activities. (B) Mass spectrometry is used to analyze the immobilized peptides. Spectra show maleimide-terminated alkanethiols before (i) and after (ii) reaction with a cysteine-terminated peptide. Treatment of the peptide with a kinase results in phosphorylation, with a mass increase of $80 \mathrm{D}$ (iii).

taneously in six solutions containing different kinases and selective inhibitors (Figure 2B). The first lane (Figure 2B, K1) contained $\mathrm{Src}$ and $\mathrm{Abl}$ and resulted in the expected phosphorylation of the P1 and P2 substrates. Addition of the small molecule Gleevec, which is an antagonist of $\mathrm{Abl},{ }^{13}$ to this mixture $(50 \mu \mathrm{M}$, lane $\mathrm{K} 2)$ resulted in a suppression of the phosphorylation of $\mathrm{P} 1$. The third lane was treated with a mixture of the CK1, PKA, and PKC kinases, resulting in phosphorylation of peptide substrates P3 and P5-P7. Addition of Gö 6850 (an inhibitor of $\mathrm{PKC}^{14}$ ) to this mixture (1 $\mu \mathrm{M}$, lane $\mathrm{K} 4$ ) resulted in a loss of phosphorylation of P6, but with no effect on the other two kinase activities. Finally, the fifth lane was treated with a mixture of the five kinases used above and resulted in phosphorylation of all six peptides. ${ }^{15}$ Addition of both 

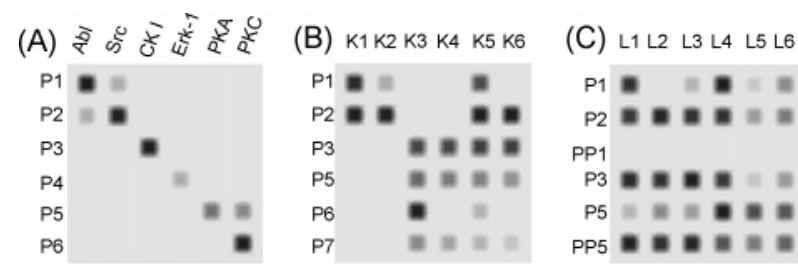

Figure 2. (A) An array that was used to profile the phosphorylation of immobilized peptides by a panel of kinases. Peptides that are patterned in horizontal lanes are indicated to the left, and samples containing kinases are denoted at the top. The intensities of the spots at each intersection of peptide and sample correspond to the extent of phosphorylation of the immobilized peptides. (B) An array that was used to evaluate selective inhibitors of kinases. (C) An array was used to profile kinase and phosphatase activities in cell lysates. The intensities of spots in lanes PP1, P3, and PP5 correspond to the extent of dephosphorylation of immobilized phosphopeptides by phosphatases (see text for explanation).

small molecule inhibitors prevented phosphorylation of the P1 and P6 substrates (lane K6). These results demonstrate that the multianalyte assays accurately report on the presence of kinase activities in samples containing multiple enzymes, and that the assays are effective for evaluating selective inhibitors of these kinases.

Finally, we show that the multi-analyte assay described above is well-suited for analysis of cell extracts. We used human K562 cells that overexpress the oncogenic $\mathrm{Bcr}-\mathrm{Abl}$ fusion protein, resulting in tyrosine hyperphosphorylation of numerous cellular substrates. ${ }^{16}$ Cell extracts were prepared and supplemented with ATP $(0.2 \mathrm{mM})$. We prepared a peptide array containing three kinase substrates (P1, P2, and P5) that report on tyrosine and Ser/Thr kinase activities and three phosphorylated peptides (P3, PP1, and PP5) that report on phosphatase activities. ${ }^{17}$

We assayed a series of cell cultures and small molecule inhibitors. The first lane (Figure 2C, L1) contained an extract from normal K562 cells and resulted in phosphorylation of P1, P2, and P5, indicating the relatively high activities of the Abl, Src, and PKA family kinases. We also observed that the phosphate groups from P3 and PP5 were removed, suggesting the protein phosphatase $2 \mathrm{~A} / 2 \mathrm{C}$ and alkaline phosphatase were also active. The second lane contained extracts from K562 cells cultured with Gleevec $(50 \mu \mathrm{M}$, L2). Mass spectra from this lane reveal that Abl kinase activity is inhibited, without affecting the other kinase activities. ${ }^{18}$ Addition of Gleevec to cell extracts not cultured with the drug (L3) gave less efficient inhibition of Abl. The more effective inhibition in the former example may be due to the sequestering of drug in cells. ${ }^{19}$ Addition of $10 \mu \mathrm{M}$ peroxide vanadate to the culture medium (L4) resulted in the inhibition of alkaline phosphatase in the cells, as shown by a decrease in dephosphorylation of PP5 and a corresponding increase in phosphorylation of P5. Extracts derived from cells that were treated with the phosphatase $2 \mathrm{~A}$ inhibitor calynulin A (20 nM, L5) gave a sharp decrease in dephosphorylation of P3. Addition of calynulin A to the cell extracts (L6) gave less inhibition on phosphatase $2 \mathrm{~A}$, again indicating the inhibition of intracellular phosphatase by calynulin $\mathrm{A}$ is more efficient.

This work provides a flexible and convenient platform for assaying enzyme activities in cell extracts. The use of a $\mu \mathrm{FN}$ allows for the immobilization of ligands in defined regions of the substrate and avoids evaporation of samples, permitting the use of small volumes. PDMS $\mu$ FNs are also readily scaled to systems having a higher channel density. The self-assembled monolayers provide low background assays of activities in complex samples and allow mass spectrometry to be used to directly determine the modification of immobilized peptides. The MS detection also allows different classes of enzymatic activities to be assayed with a single protocol. The combination of these characteristics, which have individually been demonstrated in previous work, ${ }^{4,11,20}$ into a single platform represents a significant advance in bioanalytical microsystems and will be useful in chemical biology and applied biology programs.

Acknowledgment. This work was supported by the NSFMRSEC and used the microfluidics and protein expression facilities.

Supporting Information Available: Details for fabrication of $\mu \mathrm{FNs}$, preparation of SAMs, enzyme assays, mass spectrometric analysis, and cell extract preparation. This material is available free of charge via the Internet at http://pubs.acs.org.

\section{References}

(1) (a) Delamarche, E.; Bernard, A.; Schmid, H.; Michel, B.; Biebuyck, H. A. Science 1997, 276, 779-781. (b) Ismagilov, R. F. Angew. Chem., Int Ed. 2003, 42, 4130-4132. (c) Andersson, H.; van den Berg, A. Sens. Actuators, B 2003, 92, 315-325.

(2) (a) Houseman, B. T.; Huh, J. H.; Kron, S. J.; Mrksich, M. Nat. Biotechnol. 2002, 20, 270-274. (b) Pollack, J. R.; Sørlie, T.; Perou, C. M.; Rees, C. A.; Jeffrey, S. S.; Lonning, P. E.; Tibshirani, R.; Botstein, D.; BørresenDale, A.-L.; Brown, P. O. Proc. Natl. Acad. Sci. U.S.A. 2002, 99, $12963-$ 12968. (c) Zhu, H.; Snyder, M. Curr. Opin. Chem. Biol. 2003, 7, 55-63.

(3) (a) Hadd, A. G.; Raymond, D. E.; Halliwell, J. W.; Jacobson, S. C. Ramsey, J. M. Anal. Chem. 1997, 69, 3407-3412. (b) Cohen, D. B.; ChinDixon, E.; Jeong, S.; Nikiforov, T. T. Anal. Biochem. 1999, 273, 89-97. (c) Hatch, A.; Kamholz, A. E.; Hawkins, K. R.; Munson, M. S.; Schilling, E. A.; Weigl, B. H.; Yager, P. Nat. Biotechnol. 2001, 19, 461-465.

(4) (a) Rowe Taitt, C.; Anderson, G. P.; Lingerfelt, B. M.; Feldstein, M. J.; Ligler, F. S. Anal. Chem. 2002, 74, 6113-6120. (b) Jiang, X. Y.; Ng, J. M. K.; Stroock, A. D.; Dertinger, S. K. W.; Whitesides, G. M. J. Am. Chem. Soc. 2003, 125, 5294-5295. (c) Yang, T.; Jung, S.-Y.; Cremer, P. S. Anal. Chem. 2001, 73, 165-169.

(5) See Supporting Information for references on substrate sequences.

(6) Houseman, B. T.; Gawalt, E. S.; Mrksich, M. Langmuir 2003, 19, 15221530 .

(7) (a) Delamarche, E.; Bernard, A.; Schmid, H.; Bietsch, A.; Michel, B.; Biebuyck, H. J. Am. Chem. Soc. 1998, 120, 500-508. (b) Rowe, C. A. Scruggs, S. B.; Feldstein, M. J.; Golden, J. P.; Ligler, F. S. Anal. Chem. 1999, $71,433-439$

(8) McDonald, J. C.; Duffy, D. C.; Anderson, J. R.; Chiu, D. T.; Wu, H.; Schueller, O. J. A.; Whitesides, G. M. Electrophoresis 2000, 21, 27-40.

(9) Kinase assay buffers contain $50 \mathrm{mM}$ Tris- $\mathrm{HCl}(\mathrm{pH} 7.4), 10 \mathrm{mM} \mathrm{MgCl}$, $1 \mathrm{mM}$ DTT, $100 \mu \mathrm{g} \mathrm{mL}^{-1}$ of BSA, and $0.1 \mathrm{mM}$ ATP. See Supporting Information for enzyme concentrations applied.

(10) Prior to MALDI MS analysis, the substrate $(2.5 \mathrm{~cm}$ long by $2.5 \mathrm{~cm}$ wide $)$ was treated with 2,4,6-trihydroxyacetophenone (THAP, $50 \mu \mathrm{L}, 10 \mathrm{mg}$ $\mathrm{mL}^{-1}$ in acetone)

(11) (a) Su, J.; Mrksich, M. Angew. Chem., Int. Ed. 2002, 41, 4715-4719. (b) Min, D.-H.; Su, J.; Mrksich, M. Angew. Chem., Int. Ed. 2004, 43 , $5973-5977$

(12) Phosphorylation of immobilized peptides is determined from the relative intensities of substrate and product peaks in MALDI MS spectra and assumes a linear response of peak intensity and amount of peptide.

(13) Buchdunger, E.; Zimmermann, J.; Mett, H.; Meyer, T.; Muller, M.; Druker B. J.; Lydon, N. B. Cancer Res. 1996, 56, 100-104.

(14) Toullec, D.; Pianetti, P.; Coste, H.; Bellevergue, P.; Grand-Perret, T.; Ajakane, M.; Baudet, V.; Boissin, P.; Boursier, E.; Loriolle, F. J. Biol. Chem. 1991, 266, 15771-15781.

(15) The less efficient phosphorylation of P6 may be due to limiting concentration of ATP.

(16) Daley, G. Q.; Van Etten, R. A.; Baltimore, D. Science 1990, 247, 824830.

(17) K562 cell extracts had no detectable CK I kinase activity. The peptide substrate P3 therefore only serves as a substrate for evaluating phosphatase $2 \mathrm{~A} / 2 \mathrm{C}$ activity.

(18) Druker, B. J.; Tamura, S.; Buchdunger, E.; Ohno, S.; Segal, G. M.; Fanning, S.; Zimmermann, J.; Lydon, N. B. Nat. Med. 1996, 2, 561566.

(19) Le Coutre, P.; Kreuzer, K.-A.; Pursche, S.; Bonin, M. V.; Leopold, T.; Baskaynak, G.; Dörken, B.; Ehninger, G.; Ottmann, O.; Jenke, A.; Bornhäuser, M.; Schleyer, E. Cancer Chemother. Pharmacol. 2004, 53, $313-323$

(20) (a) Min, D.-H.; Tang, W.-J.; Mrksich, M. Nat. Biotechnol. 2004, 22, 717720. (b) Sia, S. K.; Whitesides, G. M. Electrophoresis 2003, 24, $3563-3576$

JA051371O 